\title{
Variability in Protein Content of Different Species of the Genus Pleurotus Collected from the North Western Himalayan Regions of India
}

\author{
Rishu Sharma* and B.M. Sharma \\ Department of Plant Pathology, CSKHPKV, Palampur, 17062, India \\ *Corresponding author
}

\begin{tabular}{|c|c|}
\hline & $3 \mathrm{~S}$ \\
\hline & \multirow{3}{*}{$\begin{array}{l}\text { In the present study, nine species of Pleurotus and their isolates were procured } \\
\text { /collected from different sources/locations and cultivated under mushroom house } \\
\text { conditions. The crude protein content of various species viz. P.ostreatus, } \\
\text { P.sapidus, P.eryngii, P.florida, P.flabellatus, P.florida,P.cystidiosus, P.hypsizygus } \\
\text { and P.sajor caju was determined on dry weight basis using micro-kjeldahl } \\
\text { method. The protein contents varied from } 23.0 \text { per cent to } 33.7 \text { per cent in } 21 \\
\text { species/isolates of Pleurotus analysed. Five isolates belonged to P.cystidiosus, } \\
\text { four to P.ostreatus, three to P.flabellatus, two each to P.eryngii and P.fossulatus } \\
\text { and one each to P.sapidus and P.florida. Lowest protein content was found in } \\
\text { P.eryngii (23\%) and highest in P.ostreatus (33.7\%) indicating a high variability } \\
\text { among various species/isolates. }\end{array}$} \\
\hline & \\
\hline & \\
\hline
\end{tabular}

\section{Introduction}

Pleurotus spp. constitute one of the choicest edible mushrooms, it is commonly known as "Oyster Mushroom"e and in India it is commonly called as "Dhingri". The genus Pleurotus has important medicinal, biotechnological properties and environmental applications (Cohen et al., 2002. The species of Pleurotus grow in the forests, attacking both cellulose and lignin components of wood (Zadrazil and Kurtzman, 1982; Croans, 2004) and are widely cultivated in temperate, subtropical regions of the world. Representatives of genus Pleurotus form a heterogeneous group of edible species of high commercial importance (Zervakis, 2004). The total world production of mushrooms in 2010 is around 3.5 million tons as per FAO statistics (Anonymous, 2007 and Singh et al., 2011). Mushrooms are increasingly being utilized as important food products for their significant role in human health, nutrition, and disease control (Randive et al.,2012.) Pleurotus spp. constitute 25 per cent and ranks second among the cultivated mushrooms. In India, mushroom production has crossed over $1,00,000$ tons in 2012. Pleurotus production is highest in Tamil Nadu and Punjab each with 2,000 tons each. Himachal Pradesh has an annual Pleurotus production of 110 tons. (Anonymous, 2015). The species of genus 
Pleurotus show great diversity in their adaptation to the varying agro-climatic conditions. This flexib;le nature of the genus and its ease of cultivation gives it importance than any other cultivated mushroom (Zadrazil and Dube, 1992). Oyster mushroom can grow at moderate temperatures, ranging from 20 to $30^{\circ} \mathrm{C}$, and at a humidity of $55-70 \%$, on various agricultural waste materials used as substrate (Block et al., 1959).According to Croans, 2004, these mushrooms are a good source of non-starchy carbohydrates, with high content of dietary fiber and moderate quantity of proteins, including most amino acids, minerals, and vitamins. Proteins are polymers of amino acids. Twenty different types of amino acids occur naturally in proteins. (Antonio et al, 2016). Proteins differ from each other according to the type, number and sequence of amino acids that make up the polypeptide backbone. As a result they have different molecular structures, nutritional attributes and physiochemical properties (Cuniff, 1995). Proteins are important constituents of foods for a number of different reasons. They are a major source of energy, as well as containing essential amino-acids, such as lysine, tryptophan, methionine, leucine, isoleucine and valine, which are essential to human health, but which the body cannot synthesize. Proteins are also the major structural components of many natural foods. Many food proteins are enzymes which are capable of enhancing the rate of certain biochemical reactions. These reactions can have either a favorable or detrimental effect on the overall properties of foods. Food analysts are interested in knowing the total concentration, type, molecular structure and functional properties of the proteins in foods. Thus, the present experiment was done to increase the intake of vital amino acids which cannot be synthesized by our human body but are very vital for the sustenance of different life processes. Such amino acids are found in the protein blocks which are present in desirable quantities in Pleurotus mushroom and the idea is to motivate the common masses about the benefits of mushroom based diet esp those rural farmer or tribal communities which suffer malnutrition.

\section{Materials and Methods}

The experimental fruiting trials were conducted in the Mushroom House of the Department of Plant Pathology and protein estimation studies were done in the Soil Science Laboratory of the Department of Soil Science of Chaudhary Sarvan Kumar Himachal Pradesh Krishi Viswavidyalaya, Palampur, India. Pleurotus mycelia colonized packets, weighing $200 \mathrm{~g}$ each, obtained from the Mushroom spawn unit of the university were used. The cultivation substrate consisted of wheat straw in a polypropylene bag sealed with cotton wool and sterilized at $121^{\circ} \mathrm{C}$ for 20 min. Mycelial culture of the nine Pleurotus sppp/ strains collected from Directorate of Mushroom Research, Solan and from wild areas of the Himachal Pradesh were used for the fructification trials. For each Pleurotus spp./strain, three replicate bags were prepared and incubated at $25 \pm 2{ }^{\circ} \mathrm{C}$ in the Mushroom House, for full colonization of the substrate. Once fully colonized, induction of fruiting was done by removing the plastic bags with help of sterilized blade while keeping the upper portion of the bag intact. The packets were tied upside down with a rope along the wooden bamboo stands equidistantly (Fig. 1). After, the pinheads starts and fruiting matures, first flush of mushrooms from each bags was harvested. Water was sprayed regularly to maintain humidity (80-85\%). Three flushes of each packet were harvested and recorded (Fig 2). Fruiting bodies of all nine spp/ strains of Pleurotus were analyzed for nutritional composition according to the Association of Official Analytical Chemists (Chang and Miles, 1989). In the present study, the total crude protein estimation was done using the 
micro-Kjeldahl method (Anonymous, 1960), which involved three major steps viz. Digestion, Neutralization and Titration.

Samples of $1 \mathrm{~g}$ dried powder were digested in $300 \mathrm{ml}$ Kjeldahl flask with $20 \mathrm{ml}$ of concentrated sulphuric acid and $5 \mathrm{~g}$ of digestion mixture of following composition in the ratio:

Anhyhdrous copper sulphate :

Potassium sulphate $\quad: 10$

Selenium powder

0.1

$(1: 10: 0.1) \mathrm{w} / \mathrm{w}$

One part of the digestion mixture was mixed with 30 parts of sodium sulphate and stored separately in glass stoppered bottle. The digestion was allowed to continue till the mixture became colourless (i.e. free from organic carbon). Digestion mixture was then diluted to $100 \mathrm{ml}$ with distilled water after it had cooled down. Later $5 \mathrm{ml}$ of aliquot was distilled after adding $100 \mathrm{ml}$ of 40 per cent sodium hydroxide. The distillate was then collected in $100 \mathrm{ml}$ flask having $10 \mathrm{ml}$ of $40 \%$ boric acid solution. The distillation was allowed to continue till ammonia ceased to evolve. The excess of acid was neutralized by titrating with $\mathrm{N} / 100 \mathrm{H}_{2} \mathrm{SO}_{4}$ (Sulphuric Acid), total crude nitrogen was estimated as per cent dry weight. The amount of total nitrogen in the raw materials were multiplied with the traditional conversion factor of 6.25 (Maehre et al., 2018, Kjeldahl, 1883).

\section{Results and Discussion}

Mycelial cultures of six species of Pleurotus were procured from DMR, Solan and fifteen were collected from various vegetational zones of Himachal Pradesh during the monsoon months of 2005 and 2006. Thus a total of 21 species/strains were taken for further studies as shown in (Table 1). All the 21 isolates of Pleurotus were evaluated for their spawning behaviour following the standard technique (Munjal, 1973). The experimental fruiting trials were conducted under the mushroom house conditions. However, among 21 isolates only twelve showed fructification (Table 2).

Fig.1 Fruiting trials of the collected/ procured Pleurotus cultures under Mushroom house conditions

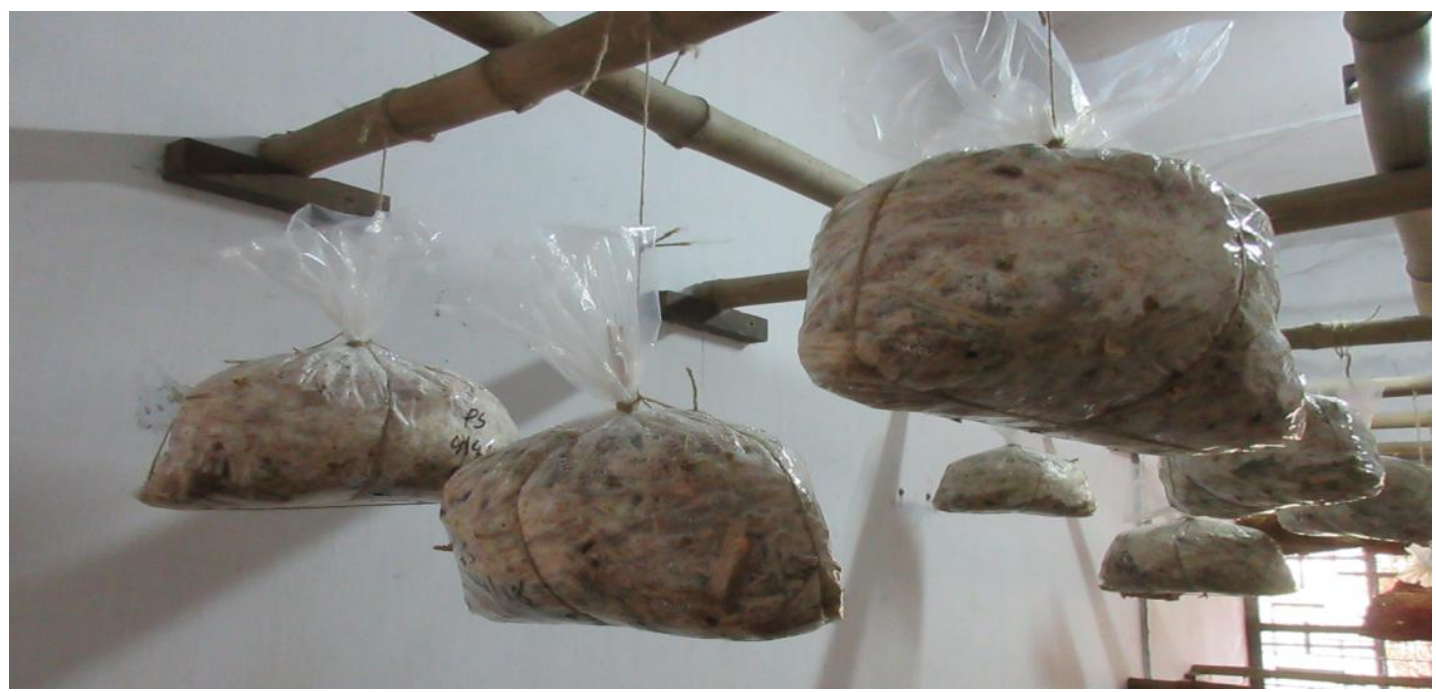


Fig.2 Fruiting Trials of Pleurotus spp./ strains
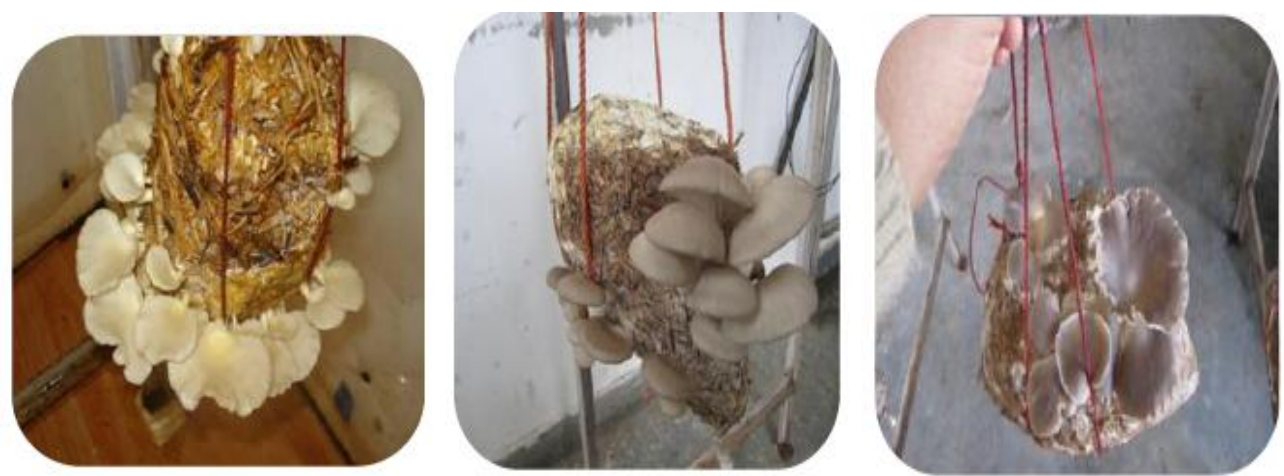

Table.1 Source of collection of various Pleurotus species / strains

\begin{tabular}{|c|c|c|}
\hline Source & Name & Species /Strains \\
\hline Collection from wild & $\begin{array}{l}\text { P11 } \\
\text { P5 } \\
\text { P21 } \\
\text { P3 } \\
\text { P4 } \\
\text { P12 } \\
\text { P6 } \\
\text { P8 } \\
\text { P10 } \\
\text { P18 } \\
\text { P19 } \\
\text { P20 } \\
\text { P7 } \\
\text { P15 } \\
\text { P17 }\end{array}$ & $\begin{array}{l}\text { Pleurotus sp.II } \\
\text { Pleurotus cystidiosus I } \\
\text { Pleurotus ostreatus IV } \\
\text { Pleurotus flabellatus II } \\
\text { Pleurotus cornucopiae } \\
\text { Pleurotus cystidiosus II } \\
\text { Pleurotus pulmonarius } \\
\text { Pleurotus fossulatus I } \\
\text { Pleurotus fossulatus II } \\
\text { Pleurotus sp.IV } \\
\text { Pleurotus sp.V } \\
\text { Pleurotus ostreatus III } \\
\text { Pleurotus sp.I } \\
\text { Pleurotus } \text { sp.III } \\
\text { Pleurotus } \text { eryngii II }\end{array}$ \\
\hline DMR, Solan & $\begin{array}{l}\text { P1 } \\
\text { P2 } \\
\text { P9 } \\
\text { P13 } \\
\text { P14 } \\
\text { P16 }\end{array}$ & $\begin{array}{l}\text { Pleurotus sapidus } \\
\text { Pleurotus flabellatus I } \\
\text { Pleurotus florida } \\
\text { Pleurotus ostreatus I } \\
\text { Pleurotus eryngii I } \\
\text { Pleurotus ostreatus II }\end{array}$ \\
\hline
\end{tabular}


Table.2 Protein content of various species / strains of Pleurotus cultivated under mushroom house conditions

\begin{tabular}{|l|l|c|}
\hline S. No & Species / Strains & $\begin{array}{c}\text { Crude Protein Content } \\
\text { (N \% X 6.25) } \text { Dry Weight Basis }\end{array}$ \\
\hline $\mathbf{1 .}$ & Pleurotus eryngii I & $\mathbf{2 7 . 3}$ \\
\hline $\mathbf{2 .}$ & Pleurotus sapidus & $\mathbf{3 1 . 4}$ \\
\hline $\mathbf{3 .}$ & Pleurotus sp.I & $\mathbf{2 9 . 5}$ \\
\hline $\mathbf{4 .}$ & Pleurotus florida & $\mathbf{2 8 . 4}$ \\
\hline $\mathbf{5 .}$ & Pleurotus flabellatus II & $\mathbf{3 0 . 4}$ \\
\hline $\mathbf{6 .}$ & Pleurotus ostreatus IV & $\mathbf{3 1 . 6}$ \\
\hline $\mathbf{7 .}$ & Pleurotus flabellatus I & $\mathbf{3 1 . 8}$ \\
\hline $\mathbf{8 .}$ & Pleurotus sp. II & $\mathbf{2 3 . 0}$ \\
\hline $\mathbf{9 .}$ & Pleurotus ostreatus III & $\mathbf{3 3 . 3}$ \\
\hline $\mathbf{1 0 .}$ & Pleurotus cornucopiae & $\mathbf{2 3 . 7}$ \\
\hline $\mathbf{1 1 .}$ & Pleurotus eryngii II & $\mathbf{3 2 . 1}$ \\
\hline $\mathbf{1 2 .}$ & Pleurotus sp.III & $\mathbf{3 3 . 7}$ \\
\hline & C.D $(\mathbf{5 \%})$ & $\mathbf{0 . 4 3}$ \\
\hline
\end{tabular}

* Average of three replications.

The crude protein content on dry weight basis was determined, using micro-Kjeldahl method with a conversion factor equal to $70 \%$ of N X 6.25. (Crisan and Sands, 1978) and it was found to be minimum (23.0\%) in Pleurotus sp.II and maximum (33.7\%) in Pleurotus sp. III. (Table 4.2). It is usually considered to be the standard method of determining protein concentration. Because the Kjeldahl method does not measure the protein content directly a conversion factor $(F)$ is needed to convert the measured nitrogen concentration to a protein concentration.

A conversion factor of 6.25 (equivalent to $0.16 \mathrm{~g}$ nitrogen per gram of protein) is used for many applications, however, this is only an average value, and each protein has a different conversion factor depending on its amino-acid composition. Similar results were obtained by Crisan and Sands, who concluded that protein content of mushrooms vary from flush to flush (Crisan and Sands, 1978) and also with the cultivation substrate (Bano and Rajaarthnam, 1982). Khydagi et al., (1998) reported protein content in various Pleurotus species between 18.5 to 36.5 which is also in congurrence to our results. Similarly, Gupta et al., (2004) calculated the percentage of nitrogen and crude protein in P. sajor caju to be from 4.22-5.89 and 18.46-27.78\% respectively. Toro et al., (2006) have reported a protein content of around $27 \%$ in strains of Pleurotus i.e IE 136, IN 18 and PORO.

\section{Acknowledgement}

Authors are grateful to National Horticultural Board for the financial assistance and Department of Plant Pathology, Department of Soil Science, CSKHPKV, Palampur, for cooperating us in conducting this experiment. 


\section{References}

Anonymous. 1960. Official Methods of Analysis. Association of Official Analytical Chemists. Washington DC. $1015 \mathrm{p}$.

Anonymous, 2007. Mushroom Production.

Anonymous, 2015. Indian Horticultural Production.

Antonio J., Ellerbroek A., Silver T., Vargas L., Peacock C.(2016). The effects of a high protein diet on indices of health and body composition - a crossover trial in resistance-trained men. Journal of the International Society of Sports Nutrition. 13:3

Bano, Z. and Rajarathnam, S. 1982. Studies on the cultivation of Pleurotus sajorcaju. Indian Journal of Mushrooms 15: 243-245.

Block, S. S., Tsao, G. and Han, L. 1959. Experiments in the cultivation of Pleurotus ostreatus. Mushroom Science 4: 309-325.

Chang ST., Miles PG. (1989) Edible Mushrooms and Their Cultivation. CRC Press, Inc., Florida, 345 p

Cohen R., Persky L., Hadar Y.(2002). Biotechnological applications and potential of wood degrading mushrooms of the genus Pleurotus. Applied Microbiology Biotechnology 58: 582-594.

Croans SC. (2004) Conversion of conifer wastes into edible and medicinal mushrooms. Forest Products Jounal, v.54, p-68-76.

Crisan, E.V. and Sands, A. 1978. Nutritional value of edible mushrooms. In: The biology and cultivation of edible mushrooms (Chang, S. T. and Hayes, W. A., eds) Academic Press, New York pp. 137-168

Cuniff, P (Ed)(1995). Official methods of analysis of AOAC. International. $16^{\text {th }}$ Edition Gaintherburg. AOAC Internnational.

Gupta, M., Sarmah, R. and Gupta, S. 2004. Nutrient composition of Pleurotus sajor-caju grown on different substrates. Journal of Food Science and Technology, Mysore 41(5): 584586.

Khydagi, K. S., Sharada, G.S. and Rao, M. 1998. Proximate composition of oyster mushrooms. Karnataka Journal of Agricultural Sciences 11(2): 548-549.

Kjeldahl, 1883. J. Neue Methode zur Bestimmung des Stickstoffs in organischen Körpern. Fresenius' J. Anal. Chem. 1883, 22, 366-382

Mæhre HK, Dalheim L, Edvinsen GK, Elvevoll EO, Jensen I-J (2018) Protein determination method matters. Foods 7:5

Munjal, R.L. 1973. Production of quality spawn of Agaricus bisporus and Volvariella spp. Indian Journal of Mushroom 1(1): 1-4.

Randive., SD. (2012). Cultivation and study of growth of Oyster mushroom on different agricultural waste substrate and its nutrient analysis. Advances in Applied Science Research, V. 3, p 1938-1949.

Singh M., Bhuvnesh V., Shwet K., Wakachaure GC. (2011).Agribusiness Activity: In Mushrooms Cultivation, Marketing and Consumption. Publisher, Directorate of Mushroom Research, ICAR, Solan pp 1-20.

Toro, G.V.D., Vega, R.C., Aguilar, M.E.G. and Lara, H.L. 2006. Biological quality of proteins from three strains of Pleurotus spp.. Food Chemistry 94(4): 494-497.

Zadrazil, F. and Dube, H.C. 1992. The oyster mushroom importance and 
prospects. Mushroom Research 1(1): 25-32.

Zardazil F., Kurtzman Jr RH. (1982). The biology of Pleurotus cultivation in the tropic tropical mushrooms, (Eds. ST Chang and TH Quimio), The Chinese University Press, HongKong, pp 227-298
Zervakis GI., Monslavo JM., Vilgalys R. (2004). Molecular phylogeny, biogeography and speciation of the mushroom species Pleurotus cystidiosus and allied taxa. Microbiology 150: 715-72.

\section{How to cite this article:}

Rishu Sharma and Sharma, B.M. 2018. Variability in Protein Content of Different Species of the Genus Pleurotus Collected from the North Western Himalayan Regions of India. Int.J.Curr.Microbiol.App.Sci. 7(06): 3528-3534. doi: https://doi.org/10.20546/ijcmas.2018.706.414 